\title{
Application Driven Theory: Rigorously Combining Applied and Basic Research Relevant to Accounting and Marketing
}

Linda L. Golden*, William W. Cooper and Patrick L. Brockett

IC2 Institute, University of Texas at Austin, USA

\section{Editorial}

Many business and social science research programs have come under attack as not being relevant or worthwhile $[1,2]$ expenditures of money in a research university. In times of financial difficulty, business school research has been viewed as either not impacting practice sufficiently, as insufficient in preparing students for business careers, or as too vocational (which some question as a goal of higher education). Pfeffer and Fong [2] gave an analysis of the criticisms and the facts related to these impressions, and the reality continues that the general perception of many is that much research in business is not relevant or cannot be generalized into practice. In this editorial we argue that accounting and marketing research can be both practically relevant and theoretically well-grounded, if a paradigm of application driven theory is adopted and rigorously applied.

We start with a brief description of the nature of research, simplifying it into two different dichotomies: 1) basic research and non-basic research on one continuum, and 2) applied research and pure research on the other. We then give illustrations from science, accounting and marketing to demonstrate each of the four possible combinations of research: pure-basic, pure-non basic, applied-basic and applied non basic when these terms are dichotomized. We discuss the lasting impact of basic research and argue for the importance of basic research as being both applied and practical when the theoretical constructs developed arise from a specific application and are then generalized. We call this research approach "Application Driven Theory" and give historical examples of impactful application driven theory in accounting and marketing. An application driven theory approach to research development insures that theories created are relevant to practice [3].

Basic research is research that is foundational in that it either opens new lines of research or cuts off existing lines of research. Basic research allows generalizations that can impact areas outside the original area for which it was invented. Examples of this from the history of science include the invention of probability theory by Pascal and Fermat, the development of the Arabic numeral system (taken from the Hindus) for recording numbers, and Pasteur's germ theory of disease. That which is not basic is deemed non-basic.

The dichotomy (or, conceptualized another way, possible continuum) between pure and applied research is more difficult, and comes from the motivation for the research rather than the impact of the research. Pure research is undertaken for greater understanding and applied research is undertaken to solve a particular problem or to be used in a specific practice. Another differentiating factor is that pure research is more generally disseminated (usually via publications) for the purpose of increasing the body of knowledge and application areas, whereas applied research often stops with the particular motivating application with little effort given to generalizations beyond the problem which gave rise to the investigation (e.g., industry consulting situations). We give illustrations of each combination in Table 1.

Consulting and general problem solving reflects non-basic applied research. In accounting, a specific audit, tax preparation or preparation of annual statements falls into this category. In marketing, consulting, designing company specific marketing or advertising plans and product placements are non-basic and applied.

Application driven theory resides in the top right quadrant of Table 1. An example of this is Fibonacci's [4] book Liber Abaci, which introduced Arabic numbers to Europe in 1202 to solve the problems in calculation of mathematics.

Had he stopped there, it would have been of interest to mathematicians but little or no other disciplines. Instead he showed how to apply these results to construct a theory of bookkeeping, of doing interest calculations and other computations of importance to merchants. According to David [5], Paccioli [6] (who is sometimes referred to as the father of accounting) copied Fibonacci's [4] book almost in its entirety and popularized the applications (such as double entry bookkeeping), showing further its uses, and creating another example of application driven theory. Thus, Fibonacci's [4] book had its origination in an applied problem, but after solving this applied problem created generalizations, as motivated by Paccioli's [6] work, outside the specific application that initiated the research.

A similar development (the invention of probability theory in 1654 by Pierre de Fermat and Blaise Pascal) started as a solution to a particular gambling problem posed by an avid gambler (the Chevalier de Méré) trying to explain why he kept losing on a gambling bet that seemed to him to be in his favor. This began the widely known area of "probability theory". Probability theory has since spread to affect all areas of scientific thought, including accounting (e.g., how to take audit samples) and marketing (e.g., consumer decision-making modeling).

Another example from marketing research is illustrated by the development of the Golden Numerical Scale for questionnaire design [7]. A very practical applied problem (a consumer attitude survey for a restaurant) motivated the problem: The researchers needed many repeated scales for multiple different restaurants in a more concise, but still accurate, presentation format. The practical problem of creating survey instruments with repeated scales across multiple restaurants by existing methods would require numerous questionnaire pages. The solution was to create a new response scale format, which was done to evaluate multiple restaurants and characteristics on a single continuous graphical scale. This scale was then generalized to multi-object and multi-attribute questionnaires in general, and published with the statistical and measurement properties of the scale investigated for

*Corresponding author: Linda L. Golden, Business and Marketing, IC2 Institute, University of Texas at Austin, USA, E-mail: utlindagolden@gmail.com

Received April 07, 2012; Accepted April 10, 2012; Published April 12, 2012

Citation: Golden LL, Cooper WW, Brockett PL (2012) Application Driven Theory: Rigorously Combining Applied and Basic Research Relevant To Accounting and Marketing. JAccount Mark 1:e103. doi: 10.4172/2168-9601.1000e103

Copyright: (c) 2012 Golden LL, et al. This is an open-access article distributed under the terms of the Creative Commons Attribution License, which permits unrestricted use, distribution, and reproduction in any medium, provided the original author and source are credited. 
Citation: Golden LL, Cooper WW, Brockett PL (2012) Application Driven Theory: Rigorously Combining Applied and Basic Research Relevant To Accounting and Marketing. J Account Mark 1:e103. doi: 10.4172/2168-9601.1000e103

Page 2 of 2

\begin{tabular}{|c|c|c|c|}
\hline & & Non-Basic & Basic \\
\hline \multirow[t]{3}{*}{ Applied } & Physical and Natural Sciences & $\begin{array}{l}\text { Consulting, engineering, software development for specific } \\
\text { applications }\end{array}$ & $\begin{array}{l}\text { Germ theory of disease (Pasteur), The periodic table of the } \\
\text { elements, Newtonian mechanics }\end{array}$ \\
\hline & Accounting & Routine income tax preparation, Compliance auditing & $\begin{array}{l}\text { Fibonacci's [4] introduction of Arabic numerals to Europe } \\
\text { (showing specific application bookkeeping and merchant cal- } \\
\text { culations), Paccioli [6] introduction of double entry accounting }\end{array}$ \\
\hline & Marketing & $\begin{array}{l}\text { Consulting, Setting market advertising buying quantities, } \\
\text { brand name testing, }\end{array}$ & $\begin{array}{l}\text { Metrics for measuring social profit enterprises, Golden numeri- } \\
\text { cal scale for survey design, consumer marketing research as } \\
\text { a statistical science (e.g. Arthur Nielsen with the founding of } \\
\text { the ACNielsen Company in 1923) }\end{array}$ \\
\hline \multirow[t]{3}{*}{ Pure } & Physical and Natural Sciences & $\begin{array}{l}\text { Number theory (e.g., theorems on perfect integers, Fibonacci } \\
\text { series, etc.), Magic Squares, }\end{array}$ & $\begin{array}{l}\text { Godel's Incompleteness Theorem, some quantum physics } \\
\text { research, Fermat's last theorem }\end{array}$ \\
\hline & Accounting & Accounting standards, behavioral accounting & $\begin{array}{l}\text { Balance sheet valuation of level } 3 \text { derivative assets (those } \\
\text { with no observable market price) which are marked to a model } \\
\text { rather than marked to market }\end{array}$ \\
\hline & Marketing & $\begin{array}{l}\text { Commercial eye-tracking research, neural marketing re- } \\
\text { search (via fMRI or other techniques) }\end{array}$ & Utility theory based consumer decision models \\
\hline
\end{tabular}

Table 1: Dichotomies of Research Approaches Combined.

uses far afield from comparisons of consumer attitudes of different restaurants (e.g., a comparison of varying country images).

It can be argued that all research in business disciplines must begin with "Application Driven Theory". If accomplished rigorously and scientifically this approach generates research results that are useful for applied industry issues, as well as having theoretical construct properties commensurate with the goals of a solid academic contribution. Not only is Application Driven Theory (i.e., start with the applied problem and develop or utilize a solid theoretical structure in its solution approach) relevant for accounting and marketing, but it is relevant to many (if not all) disciplines in and outside of a business school.

\section{References}

1. American Assembly of Collegiate Schools of Business (1996) AACSB Faculty Leadership Task Force Report.
2. Pfeffer J, Fong CT (2002) The End of Business Schools? Less Success Than Meets the Eye. Academy of Management Learning \& Education 1.

3. Cooper WW, McAlister L (1999) Can research be basic and applied? You bet. It better be for B-schools! Socioecon Plann Sci 33: 257-276.

4. Fibonacci L (1202) Liber Abaci.

5. David FN (1969) Games, God, and Gambling: A history of probability and statistical ideas. Charles Griffin \& Co., London, UK.

6. Paccioli FL (1494) Summa de arithemetica, geometria, proportioni e proportionalita.

7. Golden LL, Brockett PL, Albaum G, Zatarain J (1992) The Golden Numerical Comparative Scale Format for Economical Multi-Object/MultiAttribute Comparison Questionnaires. J Off Stat 8: 77-86.

8. Gilligan C, Golden LL (2009) Rebranding Social Good: A Social Profit Approach. Academy of Marketing Studies Journal 13: 97-117.

Unique features:

- User friendly/feasible website-translation of your paper to 50 world's leading languages

- Audio Version of published paper

Digital articles to share and explore

Special features:

200 Open Access Journals

15,000 editorial team

21 days rapid review process

Quality and quick editorial, review and publication processing

Indexing at PubMed (partial), Scopus, DOAJ, EBSCO, Index Copernicus and Google Scholar etc

Sharing Option: Social Networking Enabled

- Authors, Reviewers and Editors rewarded with online Scientific Credits

- Befter discount for your subsequent articles

Submit your manuscript at: http://www.omicsonline.org/submission 